adjacent to it. Also, with such arrangements below as those of the Victoria, it is impossible to ensure that an unforeseen accident would always allow of sufficient time to close the water-tight doors in the manner required.

The efficiency of the water-tight hatches, and the chances of their being properly secured in an emergency when they are fastened by a number of clips round the edge, as at present, is also a question that appears to require consideration; while it is to be observed that the sliding horizontal door in the protective deck of the Victoria, which opened into a shoot through which coal was trimmed from the reserve bunkers at after end of protective deck, into the side bunkers in the stokehold, could not be closed from the shoot in which the men worked who were trimming the coal; but had to be worked from the submerged torpedo room, a compartment below the protective deck. This open door had an important effect upon the capsizing, for Mr. White states that "one of the chief causes of inclination to starboard is to be found in the fact that, owing to open doors, water was able to find its way from bunkers above the protective deck, down through the coal-shoot, and so to fill No. 7 bunker just before the forward starboard stokehold."

It appears to us that one of the chief lessons taught by the circumstances of this disaster, is the necessity of reducing the number of water-tight doors and hatches, and of arranging that all of them which are essential to the efficiency of the water-tight subdivision, and are ever likely to be left without attendance while open, should be capable of being closed, either by a thoroughly satisfactory self-acting arrangement, or by appliances for working them from a deck at a safe height above water.

The points still remaining to be considered will be reserved for cur next article.

Francis Elgar.

\section{REAPPEARANCE OF THE FRESHWATER} MEDUSA (LIMNOCODIUM SOWERBII).

FOR three years nothing has been seen of the freshwater medusa in the Regent's Park, and naturalists had given up hope of carrying on any further investigation into its life-history. It seemed as though this beautiful little organism - brought we know not how or whence into the midst of London-had, like some mysterious comet, unexpectedly burst on the zoological world, and as unexpectedly disappeared.

I was, therefore, greatly astonished to hear in September, from my friend the Director of Kew, that the curator of the Sheffield Botanic Gardens (Mr. Harrow) had discovered it in quantity in the Victoria Regia tank under his care during the present summer, and I was soon after delighted by the safe arrival from Sheffield of a bottle containing living well-grown specimens of the familiar jelly-fish. Mr. Harrow informs me that he observed it in the tank at Sheffield for the first time in the beginning of June of this year (1893). Specimens were still observed as late as the middle of October-giving a duration of some fourteen weeks - an unusually long period. Mr. Harrow estimates the total number seen as at least 300 .

The last seen in the Botanic Gardens, Regent's Park, London, were taken from the new Victoria Regia tank on July 30, 1890 . The question as to how the jelly-fish got to Sheffield is easily answered. Water plants (Nymphæaceæ and Pontederia) were sent (as I am informed by Mr. Sowerby and by Mr. Harrow) from Regent's Park to Sheffield to re-stock the tank there on April 4, I892, and on April 7, 1893. Hence there was the probability of some of whatever reproductive germs of Limnocodium. existed in Regent's Park being transferred to Sheffield. The curious thing is that in 1892 and in 1891 no Limnocodium were seen in the original source-viz. the Regent's
Park tank-nor in 1893 , excepting a few sent from Sheffield and placed in that tank by Mr. Sowerby.

This is the first instance recorded in which another Victoria Regia tank has been "infected" with Limnocodium from the original Regent's Park tank, excepting when the new tank in Regent's Park was in I89o infected from the old one-by the transference to it of weeds and roots containing the germs of the jelly-fish.

The tank at Kew has never been properly infected, for it is, I regret to say, the anti-zoological custom at the Royal Gardens to thoroughly cleanse, wash, and furbish up the Victoria Regia tank every year so thoroughly that the winter germs of the jelly-fish are removed or destroyed. Hence Limnocodium has flourished at Kew when sent there from Regent's Park, but has never "carried over" from one season to another. It is, fortunately, the custom in other botanical gardens to leave a quantity of "sludge" (including some old leaves and stems) at the bottom of the tank, when the water is drawn off and the soil prepared for a new season, and hence Limnocodium has been preserved from destruction for so many years.

As to what is the precise nature of the process by which Limnocodium has been carried over from one season to another in the Regent's Park, we are still uncertain. The facts at first ascertained were these, viz. that the jelly-fish suddenly appear each year as early as April or as late as August, and remain for from five to twelve weeks, when they die down and absolutely disappear. During the first few weeks of their appearance the water is found to contain an immense number of minute young forms ( $\frac{\pi}{30}$ of an inch in diameter), which I described and figured in the Quart. Journ. Micros. Science, vol. xxi. p. 194. Evidently these young were being produced in quantity in the tank, and gradually developed to the full size of half an inch diameter. The form and appearance of these young were such as to lead me to the conclusion (subsequently found to be erroneous) that they had been developed from eggs. At the same time the remarkable fact was established by the examination in successive years of many hundred specimens that the adult Limnocodia were every one, without exception, males. They produced abundant motile spermatozoa, but not a trace of an egg-cell was ever found in any one of them!

The hypothesis which I entertained in I884 as an explanation of this curious state of things was-that the female was a non-motile, perhaps a fixed hydriform organism, and I accordingly searched for such a form in the mud and debris from the bottom of the tank. At last, in a large quantity of such material which I obtained when the tank was cleared out in the winter of I 884 , my assistant, Dr. A. G. Bourne, found a very strange diminutive polyp adhering in numbers to the rootfilaments of Pontederia. This polyp he carefully described in the same year in a communication to the Royal Society. There was very great probability that this little polyp, devoid of tentacles, and not more than $\frac{1}{8}$ th of an inch long, was the "trophosome" of the Limnocodium medusa. That this was a true inference was subsequently proved by Dr. G. H. Fowler, who in 1890 (Quart. Journ. Micros. Science, vol. xxx.), the last year in which the jelly-fish were seen in London, showed that the little spherical young found floating in the water of the tank are nipped off by a process of transverse fixion from the free ends of the minute polyps described by Bourne.

Fowler (whose observations were made in my laboratory in 1888) found the polyps very abundantly upon floating water-plants widely scattered in the tank; they were also detected by Mr. Parsons, of the Quecket Club, in water which was the overflow of the tank, and accumulated in an outside reservoir.

The immediate question then became "How do the polyps originate?" The polyps account for the medusæ, NO. I 258 , vol. 49] 
but whence do they themselves originate? And this question still remains unsolved. The polyps are observed to increase by budding, but they never form clusters of more than four "persons." How do they become distributed over the under surface of nearly all the floating leaves in the tank? How do they get carried to an outside reservoir? Is it not improbable that they would continue year after year to propagate themselves by budding as polyps, and in the summer to throw off successive crops of male medusæ? It is possible that this is the whole history, but not quite probable.

In any case, however, the existence of the minute polyps attached to water-plants is sufficient to explain the introduction of the jelly-fish to Sheffield. It also is sufficient to explain the original introduction of the jellyfish to the Regent's Park, since in 1878 (two years before the first discovery of the jelly-fish) specimens of a remarkable water-plant (Pontederia) were brought from Brazil by a lady and presented to the Botanical Society, and placed in the Victoria Regia tank.

A new interest has recently been added to that already attaching to Limnocodium by the description of another fresh-water jelly-fish, the Limnocnida Tanganyisice. This remarkable form was worked out in my laboratory in Oxford during last winter by Mr. R. T. Günther, who received the specimens from his father, Dr. Günther, F.R.S., of the British Museum. Dr. Günther had written to the Mission on Lake Tanganyika in order to procure the specimens. Individuals of three kinds are described by Mr. Günther, viz. males, females, and a-sexual individuals which produce crops of buds on the manubrium (see his papers in the Ann. and Mag. Nat. Hist., I893, and in the forthcoming number of the Quart.Journ. Micros. Science). Whilst differing greatly from Limnocodium in most respects, Limnocnida agrees with it, in a most extraordinary way, in the minute structure of the marginal sense-organs. No light is thrown by Limnocnida on the problem of the life-history of Limnocodium.

I subjoin a list of dates in reference to the history of Limnocodium, and may add that the columns of NATURE already contain numerovs communications relative to it, viz. in vol. xxii. (1880), pp. 147, 177, 178, 190, 218 , $24 \mathrm{r}, 290$, and in vol. xxxi. p. 107.

I880.-June ro, first observed in Regent's Park; remained six weeks.

I881.- June I2; reappeared; remained five weeks.

1882. - None observed.

I883.-April 28; twelve weeks.

1884. -April 27; twelve weeks (?).

1885. - April 5 (no record of duration).

1886. - August 7 (no record of duration)

1887. - End of May (no record of duration).

1888. - May Io (no record; very few observed).

I889. - None.

I890. - New tank constructed and stocked; July Io a few.

1891.- - None.

1892.- None. Plants sent to Sheffield April 4.

1893.- None in London. Plants again sent, April 7, to Sheffield.

r893.- -June 7 to mid-October, large numbers observed in tank at Sheffield.

Hydroid trophosome discovered by Bourne in winter of 1884 . Production of medusæ by hydroid, observed by Fowler, in May, 1888. E. Ray LaNKESTer.

\section{DEATH OF PROF TYNDALL.}

A NOTHER of our "Scientific Worthies" has" "crossed the bar," leaving behind an honoured name and works that will perpetuate his memory. On Monday evening Prof. Tyndall passed away at his residence, near Haslemere. For some time previous he had been suffering from insomnia and rheumatism, and very unfavourable symptoms set in on Monday morning. He quickly became unconscious, and except for a brief interval at midday, remained in this state until half-past six o'clock, when a peaceful change from life to death took place. It appears that the cause of death was an overdose of chloral, which Prof. Tyndall took as a sedative against insomnia. He had been in the habit of taking narcotics for several years past in order to overcome the sleeplessness from which he suffered. On Monday about the usual quantity was administered to him, but his greatly weakened condition was unable to bear so much. The inquest on the body, which was considered necessary by the doctors, was held yesterday.

A detailed account of Tyndall's life was given in these columns in August, 1874 , so it is only necessary to trace now a brief outline of his career. He was born in 1820 , at Leighlin Bridge, near Carlow, in Ireland. But it was not until 1847 that he began his career as a teacher of science, by accepting a post in Queenwood College, Hampshire, where Dr. Frankland was chemist. A year later the two friends did what every young man of science should do, if possible-they went together to a German University, the University of Murburg, Hesse Cassel, rendered celebrated by Bunsen and others; and to Bunsen, whose lectures he attended, and in whose laboratory he worked, Tyndall was never tired of expressing his obligations. He was at Murburg when Knoblauch, preceded by a distinguished reputation, and accompanied by a choice collection of instruments, went there as Extraordinary Professor. Subsequently, in conjunction with Knoblauch, Tyndall carried on his " classic" inquiries in connection with diamagnetism, afterwards prosecuting his research in the laboratory of Prof. Magnus at Berlin. In $185 \mathrm{I}$ his life-long friendship with Prof. Huxley commenced, and in the following year he was elected a Fellow of the Royal Society. In February, I 853 , he gave the first of his eloquent Friday evening lectures at the Royal Institution. Shortly afterwards, at the proposal of Faraday, he was appointed Professor of Physics in the Institution, a post from which he retired in I887. The managers and members of the Institution marked their sense of the benefits he had conferred upon it by electing him as Honorary Professor, a title previously borne by Davy and Brande, and by calling one of the annual courses of lectures "The Tyndall Lectures." His bust was also placed in the Institution in memory of his relations with it.

A complimentary dinner was given to Tyndall on the occasion of his retirement from the Chair of Physics in the Royal Institution. The body of eminent men which met at the dinner was such as has seldom if ever been brought together to do honour to a man of science, and when the chairman, Sir George Stokes, the then President of the Royal Society, gave voice to the desire of the company that their guest should long enjoy the leisure which he had so well earned, it was not thought that after but six years of rest from labour he would be called away. The speeches made at the dinner are reported in NATURE, vol. xxxvi. p. 222, and they show the high regard in which Tyndall was held throughout the world of science, art, and letters. In responding to the toast of the evening, he gave an account of his life, including in his speech the following true remarks:- " To keep technical education from withering, and to preserve the applications of science from decay, the roots of both of them must be imbedded in the soil of original investigation. And here let it be emphatically added, that in such investigation practical results may enter as incidents, but must never usurp the place of aims. The true son of science will pursue his inquiries irrespective of practical considerations. $\mathrm{He}$ will ever regard the acquisition and expansion of natural knowledge-the unravelling of the complex web of nature by the disciplined intellect of man, as his noblest end, and not as a means to any other end." This was the kind of spirit that actuated Tyndall throughout his career. It

NO. I 258 , VOL. 49] 